\title{
Pulmonary Lymphangioleiomyomatosis; Unusual Radiological Manifestation of Multiple Large Nodules
}

\author{
Kazuhiko Suzuki, Hiroshi TanaKa, Masanori ShIRatori, Gen Yamada, Takayuki Itoh, \\ Shintaro Tanaka, Manabu Nagata, Hitoki Saizen, Masaaki SatoH* and Shosaku AbE
}

\begin{abstract}
A 44-year-old woman was admitted to our hospital in August 1999 for multiple large nodules detected on chest roentgenogram in an annual health check. Chest CT scans showed bilateral large nodules $(>10 \mathrm{~mm}$ in diameter) with irregular margins and multiple thin walled cystic lesions. From these radiologic examinations, we suspected pulmonary Langerhans cell histiocytosis. Histological examination of the biopsy specimen by video-assisted thoracoscopy revealed a marked proliferation of the spindle cells, which were immunologically positive for alpha-smooth muscle actin and HMB-45, in the cyst walls and lung parenchyma. The large nodules consisted of proliferation of the smooth muscle cells surrounded by a dense layer of hemosiderinladen macrophages. During the two years subsequent to these 1999 examinations, the opacities have gradually diminished and the patient was found to have pulmonary lymphangioleiomyomatosis. This case exhibited rare radiologic manifestations of multiple large nodules mimicking Langerhans cell histiocytosis.

(Internal Medicine 41: 879-882, 2002)
\end{abstract}

Key words: lymphangiomyomatosis, hemorrhage, Langerhans cell histiocytosis

\section{Introduction}

Pulmonary lymphangioleiomyomatosis (PLAM) is a rare disease, characterized by the non-neoplastic proliferation of atypical smooth muscle cells within the lung parenchyma, a predominantly peribronchovascular proliferation of the cells associated with airway and vascular obstruction, progressive loss of lung function and ultimately death (1). The radiological abnormalities of PLAM are consistent with ground-glass opacities and multiple cystic lesions accompanied by small nodules whose average size is under $5 \mathrm{~mm}$ (2).
Pulmonary Langerhans cell histiocytosis $(\mathrm{LCH})$ is also a rare lung disease characterized by lung infiltrates composed of Langerhans' histiocytes (3), and the radiographic appearance of LCH consists of cystic lesions and multiple nodular opacities ranging on average from 1 to $5 \mathrm{~mm}$, the largest being 10 $\mathrm{mm}$ in diameter $(4,5)$.

Both PLAM and LCH have similar pulmonary cysts, which are defined as air-containing lesions surrounded by thin walls that are not shared, but in general parenchymal large nodules, when present, are helpful in distinguishing LCH from PLAM (6). We describe a case of PLAM with an unusual presentation of large nodular lesions, mimicking LCH.

\section{Case Report}

A 44-year-old woman, current smoker, was admitted to our hospital in August 1999 for evaluation of pulmonary nodules found on chest X-ray film in an annual health check. She had undergone an operation to remove her uterus, but not her ovaries, for uterine cervical cancer in 1993. On admission she was $152 \mathrm{~cm}$ tall and weighed $76 \mathrm{~kg}$. Her radial pulse rate was 84/ $\mathrm{min}$ and regular. There was no abnormality in her physiological findings including auscultation of the lung. The liver and renal function tests were both within normal limits except for the high level of serum $\gamma$-GTP. Serum tumor markers were all within normal limits except that carbohydrate antigen 125 was $21.0 \mathrm{U} / \mathrm{ml}$ (normal $<18.0$ ). Arterial blood gas study in room air showed $\mathrm{PaO}_{2}$ 84.8 Torr, $\mathrm{PaCO}_{2} 34.1$ Torr, and $\mathrm{pH}$ 7.427. Pulmonary function test was performed but there were slight changes (Table 1). Chest roentgenograms on admission revealed bilateral nodular shadows (Fig. 1) and chest CT scans showed multiple thin walled cystic lesions and multiple nodules (10 to $15 \mathrm{~mm}$ in diameter) in both lungs (Fig. 2). No pleural effusion was found. And abdominal CT scans showed no abnormal findings except that her uterus had been removed. From these radiologic examinations, we suspected this case as having $\mathrm{LCH}$ or even metastatic lung cancer considering that she had undergone an operation for uterine cervical cancer. To confirm the diagnosis, video-assisted thoracoscopic biopsies from the left

From the Third Department of Internal Medicine, and *the Department of Pathology, Sapporo Medical University School of Medicine, Sapporo

Received for publication January 28, 2002; Accepted for publication June 10, 2002

Reprint requests should be addressed to Dr. Kazuhiko Suzuki, the Third Department of Internal Medicine, Sapporo Medical University School of Medicine, South-1, West-16, Chuo-ku, Sapporo 060-8543 
Table 1. Laboratory Data on Admission

\begin{tabular}{|c|c|c|c|}
\hline Hematology & & Serology & \\
\hline $\mathrm{RBC}$ & $423 \times 10^{4} / \mathrm{mm}^{3}$ & $\underline{\mathrm{CRP}}$ & $0.36 \mathrm{mg} / \mathrm{dl}$ \\
\hline $\mathrm{Hb}$ & $13.0 \mathrm{~g} / \mathrm{dl}$ & $\mathrm{IgG}$ & $1,330 \mathrm{mg} / \mathrm{dl}$ \\
\hline WBC & $8,700 / \mathrm{mm}^{3}$ & $\operatorname{Ig} \mathrm{A}$ & $228 \mathrm{mg} / \mathrm{dl}$ \\
\hline Neut & $58 \%$ & $\operatorname{IgM}$ & $90 \mathrm{mg} / \mathrm{dl}$ \\
\hline Lymp & $30 \%$ & & \\
\hline Mon & $7 \%$ & \multicolumn{2}{|l|}{ Tumor markers } \\
\hline Eos & $5 \%$ & CEA & $2.4 \mathrm{ng} / \mathrm{ml}$ \\
\hline Plt & $26.6 \times 10^{4} / \mathrm{mm}^{3}$ & SCC & $0.6 \mathrm{ng} / \mathrm{ml}$ \\
\hline \multirow[t]{2}{*}{ ESR } & $16 \mathrm{~mm}(1 \mathrm{~h})$ & SLX & $23.8 \mathrm{U} / \mathrm{ml}$ \\
\hline & & CYFRA-21 & $<0.5 \mathrm{ng} / \mathrm{ml}$ \\
\hline Biochemistry & & CA125 & $21.0 \mathrm{U} / \mathrm{ml}$ \\
\hline $\mathrm{TP}$ & $6.8 \mathrm{~g} / \mathrm{dl}$ & & \\
\hline AST & $19 \mathrm{IU} / l$ & \multicolumn{2}{|c|}{ Blood gas analysis (room air) } \\
\hline ALT & $26 \mathrm{IU} / l$ & $\mathrm{PaO}_{2}$ & 84.8 Torr \\
\hline $\mathrm{LDH}$ & $324 \mathrm{IU} / \mathrm{l}$ & $\mathrm{PaCO}_{2}$ & 34.1 Torr \\
\hline ALP & $123 \mathrm{IU} / l$ & $\mathrm{pH}$ & 7.427 \\
\hline$\gamma$-GTP & $65 \mathrm{IU} / \mathrm{l}$ & & \\
\hline BUN & $16 \mathrm{mg} / \mathrm{dl}$ & \multicolumn{2}{|c|}{ Pulmonary function test } \\
\hline $\mathrm{Cr}$ & $0.6 \mathrm{mg} / \mathrm{dl}$ & $\mathrm{VC}$ & $3.37 l$ \\
\hline $\mathrm{Na}$ & $138 \mathrm{mEq} / \mathrm{l}$ & $\% \mathrm{VC}$ & $126.2 \%$ \\
\hline $\mathrm{K}$ & $3.8 \mathrm{mEq} / \mathrm{l}$ & $\mathrm{FEV}_{1}$ & $2.76 l$ \\
\hline $\mathrm{Cl}$ & $104 \mathrm{mEq} / \mathrm{l}$ & $\mathrm{FEV}_{1} \%$ & $84.9 \%$ \\
\hline \multirow[t]{5}{*}{ FBS } & $87 \mathrm{mg} / \mathrm{dl}$ & TLC & $5.03 l$ \\
\hline & & $\% \mathrm{TLC}$ & $125.8 \%$ \\
\hline & & RV & $1.66 l$ \\
\hline & & $\% \mathrm{RV}$ & $116.9 \%$ \\
\hline & & $\%$ DLco & $84.2 \%$ \\
\hline
\end{tabular}

$S^{5}$ and $S^{8}$ were performed, and histological examination of the biopsy specimens revealed that the large nodules consisted of a marked proliferation of spindle cells and cyst walls covered with the same kind of cells. In the immunohistological examination these cells stained positively for alpha-smooth muscle actin and HMB-45. Additionally, the nodular lesions were surrounded by a dense layer of hemosiderin-laden macrophages (Figs. 3A, B and 4). From these results she was found to have PLAM.

Because she was asymptomatic and she would soon be postmenopausal, she received no specific treatment for PLAM. Although the cystic lesions in the lung fields are worsening, the nodules have markedly diminished in the last 2 years (Fig. 5).

\section{Discussion}

The characteristic CT finding of LAM consists of numerous air-filled cysts surrounded by normal lung parenchyma ( 1 , 2). And rarely a few small nodular opacities can be seen (7). Nodules in LCH consist of several types of inflammatory cells including Langerhans' cells, and the majority of them measure 1 to $5 \mathrm{~mm}$ in diameter (5). It is suggested that the presence of these parencymal nodules is helpful to distinguish $\mathrm{LCH}$ from PLAM $(6,8)$. Recently, Keyzer et al (7) described a case of PLAM that mimicked LCH by demonstrating cavitary nod-

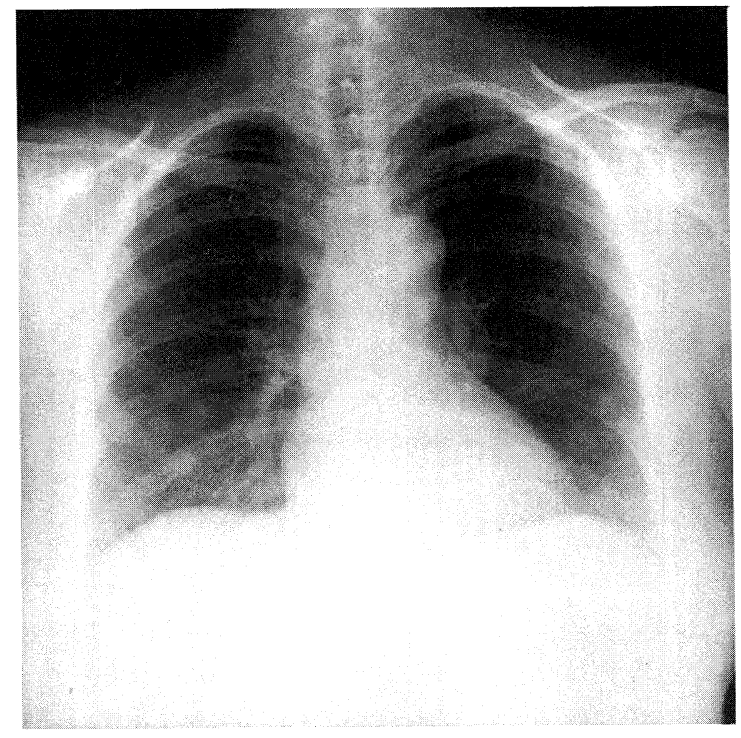

Figure 1. Chest roentgenogram on admission shows bilateral large nodules in the middle and lower lung fields.

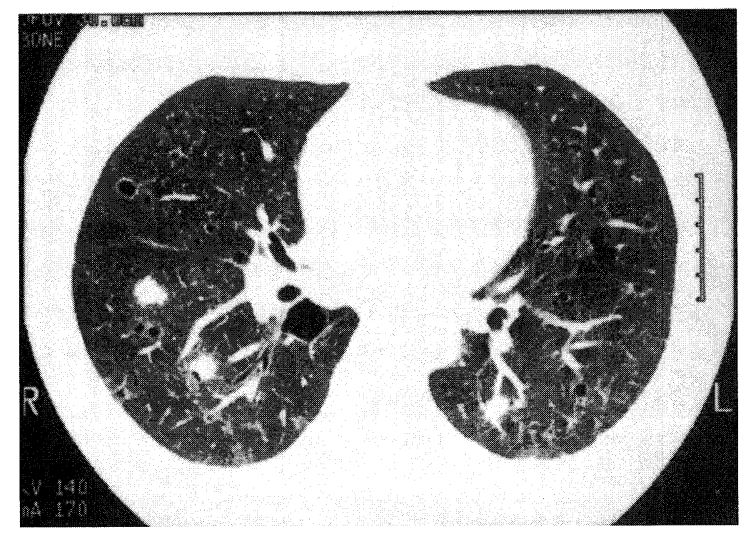

Figure 2. Chest CT scan on admission shows multiple nodules ranging from 10 to $15 \mathrm{~mm}$ in diameter, ground-glass opacities, and cysts.

ules ranging from 3 to $4 \mathrm{~mm}$ in diameter and thin-walled cysts, but to our knowledge, there has been no case report of PLAM presenting multiple large nodules of more than $10 \mathrm{~mm}$ in diameter. In this case, histological examination of the biopsy specimens revealed a large nodule composed of PLAM cells surrounded by a thick layer of hemosiderin-laden macrophages. The size of the nodule has decreased in the 2 years since the biopsy. In ordinary PLAM cases, hemorrhage is common and radiological findings reveal ground-glass opacities. Additionally, minute (1 to $3 \mathrm{~mm}$ ) nodules consisting of type II cell hyperplasia on CT scans are revealed in some patients with $\operatorname{PLAM}(9,10)$. However, there were no such pathological find- 


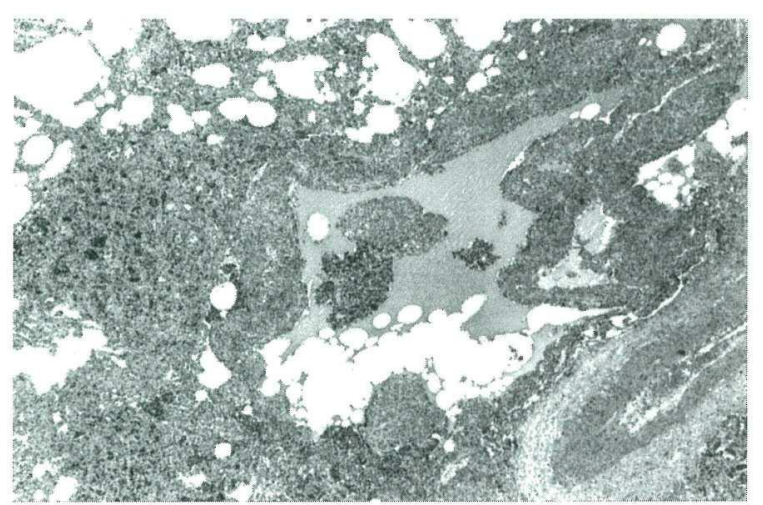

A

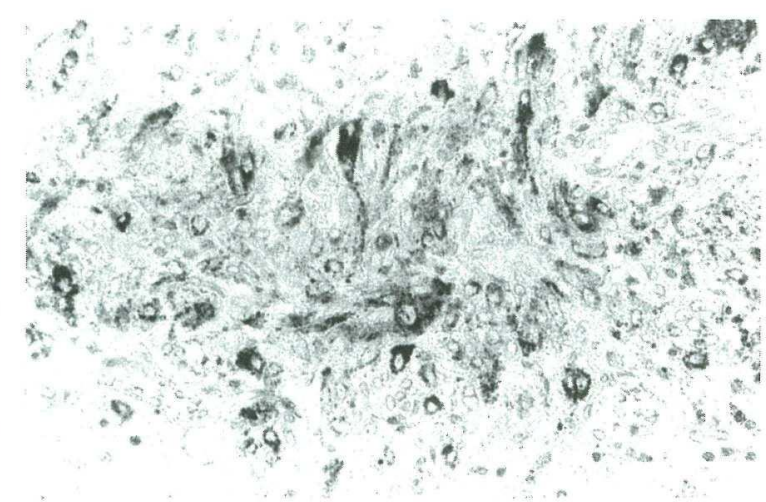

$\mathrm{B}$

Figure 3. A: Biopsy specimens demonstrate a marked proliferation of the spindle cells in the wall of cyst, which surrounded by macrophages (HE stain,$\times 34$ ). B: Immunohistochemical study shows positive reactivity of the proliferating cells for HMB-45 $(\times 340)$.

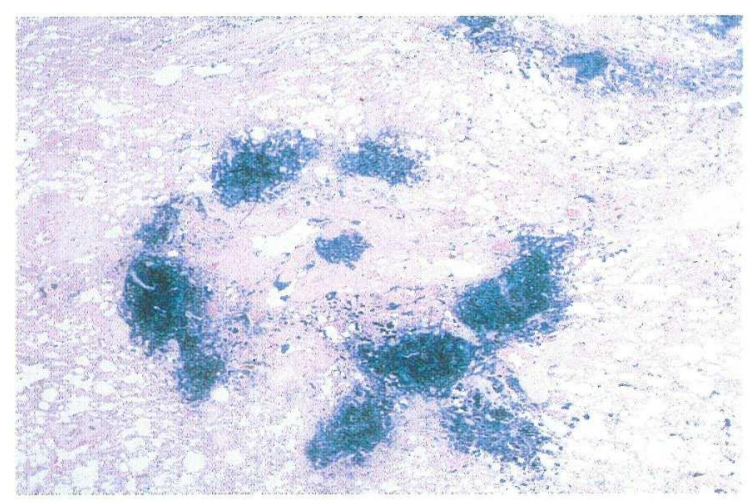

Figure 4. A large focus of proliferated smooth muscle cell is surrounded by a dense layer of hemosiderin-laden macrophage stained as blue (Iron stain, $\times 9$ ).

ings in the present case. We could not elucidate the reason why so many hemosiderin-laden macrophages remained in existence for such a long time. There has been no case report presenting bilateral large nodules as a radiological manifestation of PLAM.

The abnormal smooth muscle cells in LAM are immunophenotypically distinct in that they express a melanogenesisassociated antigen recognized by HMB- 45 and also frequently express estrogen and progesterone receptor proteins (11-13). In the present case the smooth muscle cells were showed positive for HMB-45, therefore this patient was diagnosed as having PLAM. However, before the biopsy the radiologic findings led us to suspect $\mathrm{LCH}$ or even metastatic lung cancer.

PLAM is an uncommon disease characterized by patchy proliferation of smooth muscle cells unique to this disease. But
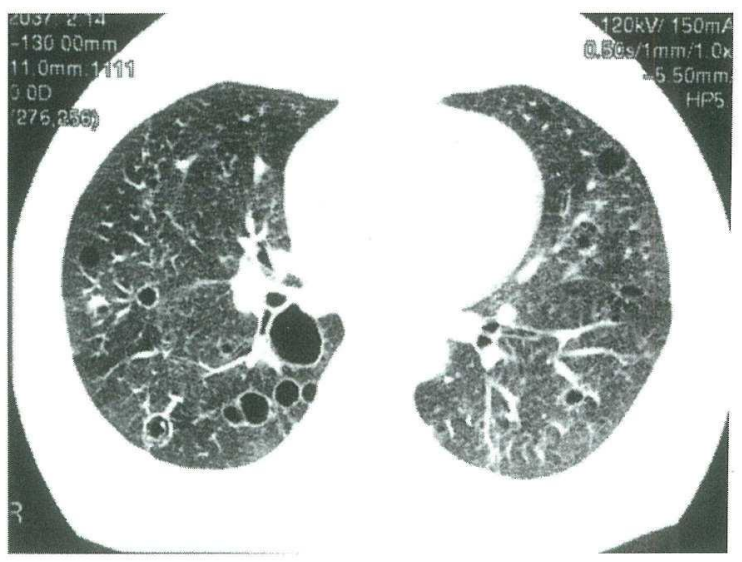

Figure 5. Chest CT scan 2 years after thoracoscopy shows that the nodules nearly disappear in spite of the fact that the cystic lesions are increasing.

the cause and pathogenesis of LAM are not known yet. There is a significant overlap between LAM, angiomyolipoma, and the syndrome of tuberous sclerosis (14). It has been shown that the smooth muscle found in PLAM is similar histologically and immunohistochemically to that found in angiomyolipoma (11). The suggestion that PLAM is a forme fruste of tuberous sclerosis is strengthened by the findings that patients with LAM also have angiomyolipoma (15). But in the present case, renal angiomyolipoma was not seen on CT scans.

The pulmonary function pattern of LAM is generally typical of obstruction resembling that of pulmonary emphysema. Total lung capacity, vital capacity and residual volume are usually normal or increased, and DLco is contrary reduced (16). But this case had a slight increase of total lung capacity and a normal DLco value, and these parameters did not change even 


\section{SuzuKI et al}

after 2 years. Based on these results, the present case might be considered an early stage of PLAM.

\section{References}

1) Sullivan EJ. Lymphangioleiomyomatosis. Chest 114: 1689-1703, 1998.

2) Kirchner J, Stein A, Viel K, et al. Pulmonary lymphangioleiomyomatosis; high-resolution CT findings. Eur Radiol 9: 49-54, 1999.

3) Von Essen S, West W, Sitorius M, Rennard SI. Complete resolusion of roentgenographic changes in a patient with pulmonary histiocytosis. Chest 98: 765-767, 1990.

4) Powers MA, Askin FB, Cresson DH. Pulmonary eosinophilic granuloma. 25-year follow-up. Am Rev Respir Dis 129: 503-507, 1984.

5) Brauner MW, Grenier P, Mouelhi MM, Mompoint D, Lenoir S. Pulmonary histiocytosis X: Evaluation with high-resolution CT. Radiology 172: 255-258, 1989.

6) Rappaport DC, Weisbrod GL, Herman SJ, Chamberlain DW. Pulmonary lymphangioleiomyomatosis: high resolution CT findings in four cases. AJR 152: 961-964, 1989.

7) Keyzer C, Bankier AA, Remmelinck M, Gevenois PA. Pulmonary lymphangiomyomatosis mimicking langerhans cell histiocytosis. J Thorac Imag 16: 185-187, 2001.

8) Bonelli FS, Hartman TE, Swensen SJ, Sherrick A. Accuracy of high-resolution CT in diagnosing lung diseases. AJR 170: 1507-1512, 1998.
9) Franz DN, Brody A, Meyer C, et al. Mutational and radiographic analysis of pulmonary disease consistent with lymphangioleiomyomatosis and micronodular pneumocyte hyperplasia in women with tuberous sclerosis. Am J Respir Crit Care Med 164: 661-668, 2001.

10) Muir TE, Leslie KO, Popper $\mathrm{H}$, et al. Micronodular pneumocyte hyperplasia. Am J Surg Pathol 22: 465-472, 1998.

11) Bonetti F, Chiodera PL, Pea M, et al. Transbronchial biopsy in lymphangiomyomatosis of the lung: HMB45 for diagnosis. Am J Surg Pathol 17: 1092-1102, 1993.

12) Berger U, Khaghani A, Pomerance A, Yacoub MH, Coombes RC. Pulmonary lymphangioleiomyomatosis and steroid receptors: an immunocytochemical study. Am J Clin Pathol 93: 609-614, 1990.

13) Burger CD, Hyatt RE, Staats BA. Pulmonary mechanics in lymphangioleiomyomatosis. Am Rev Respir Dis 143: 1030-1033, 1991.

14) Bernstein SM, Newell JD Jr, Adamczyk D, Mortenson RL, King TE Jr, Lynch DA. How common are renal angiomyolipomas in patients with pulmonary lymphangiomyomatosis? Am J Respir Crit Care Med 152: 2138-2143, 1995.

15) Kitaichi M, Nishimura K, Ito H, Izumi T. Pulmonary lymphangioleiomyomatosis; a report of 46 patients including a clinicopathologic study of prognostic factors. Am J Respir Crit Care Med 151: 527-533, 1995.

16) Tanaka H, Imada A, Morikawa $T$, et al. Diagnosis of pulmonary lymphangioleiomyomatosis by HMB45 in surgically treated spontaneous pneumothorax. Eur Respir J 8: 1879-1882, 1995. 